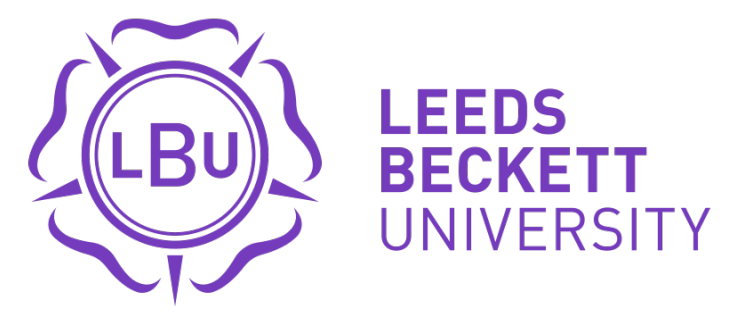

Citation:

Nasir, MA and Duc Huynh, TL and Xuan Tram, HT (2019) Role of financial development, economic growth \& foreign direct investment in driving climate change: A case of emerging ASEAN. Journal of Environmental Management, 242. pp. 131-141. ISSN 0301-4797 DOI: https://doi.org/10.1016/j.jenvman.2019.03.112

Link to Leeds Beckett Repository record:

https://eprints.leedsbeckett.ac.uk/id/eprint/6326/

Document Version:

Article (Accepted Version)

Creative Commons: Attribution-Noncommercial-No Derivative Works 4.0

The aim of the Leeds Beckett Repository is to provide open access to our research, as required by funder policies and permitted by publishers and copyright law.

The Leeds Beckett repository holds a wide range of publications, each of which has been checked for copyright and the relevant embargo period has been applied by the Research Services team.

We operate on a standard take-down policy. If you are the author or publisher of an output and you would like it removed from the repository, please contact us and we will investigate on a case-by-case basis.

Each thesis in the repository has been cleared where necessary by the author for third party copyright. If you would like a thesis to be removed from the repository or believe there is an issue with copyright, please contact us on openaccess@leedsbeckett.ac.uk and we will investigate on a case-by-case basis. 


\title{
Role of Financial Development, Economic Growth \& Foreign Direct Investment in Driving Climate Change: A Case of Emerging ASEAN
}

\author{
Muhammad Ali Nasir*1, Toan Luu Duc Huynh ^, Huong Thi Xuan Tram ^ \\ *Leeds Beckett University, United Kingdom. \\ ${ }^{\wedge}$ School of Banking, University of Economics Ho Chi Minh City
}

\begin{abstract}
In the context of remarkable economic growth and financial development in the emerging economies of East Asia, this paper attempts to shed light on the ecological consequences $\left(\mathrm{CO}_{2}\right.$ emission) of economic growth, foreign direct investment (FDI) and financial development in the selected ASEAN-5 economies. Drawing on the data from 1982 to 2014, we employed a set of quantitative techniques for panel data analysis which entailed Dynamic Ordinary Least Squares (DOLS) and Fully Modified OLS (FMOLS) approaches. Our findings indicate that financial and economic development, as well as FDI, have a statistically significant long-run co-integrating relationship with environmental degradation $\left(\mathrm{CO}_{2}\right.$ emissions) in the under-analysis economies. It showed that in ASEAN-5 countries, economic growth, financial development and FDI leads to an increase in environmental degradation. The quadratic term for economic growth showed a negative impact on environmental degradation i.e. Environmental Kuznets Curve (EKC). Our key findings manifest and emphasise the importance of appropriate policies for more inclusive economic and financial development and sustainable foreign direct investment which does not impede on the environment.
\end{abstract}

JEL Classification : F14, F15, F43, E31, Q41, Q43

Keywords: ASEAN, Economic Growth, Pollution Heavens Hypothesis (PHH), Environmental Kuznets Curve (EKC), Emerging Economies, Financial Development, FDI, $\mathrm{CO}_{2}$ emission, FMOLS, DOLS.

${ }^{1}$ Corresponding Author: Economics, Analytics \& International Business Group, Leeds Business School, Leeds Beckett University, The Rose Bowl, Portland Crescent, Leeds, LS1 3HB, UK, Email: m.a.nasir@ leedsbeckett.ac.uk Acknowledgement: This research is fully funded by the University of Economics Ho Chi Minh City 


\section{Introduction}

The $21^{\text {st }}$ Century is marked as the Asian Century and a manifestation of this is prima evident in the fact that the emerging economies of Asia have been shouldering the global growth since the Global Financial Crisis of 2008. In this regard, the Association of Southeast Asian Nations (ASEAN) has appeared as a significant economic block. As it stands, the ASEAN Economic Community (AEC) comes as a market of over US\$2.6 trillion and a population of over 622 million growing at an impressing growth rate of around 5.2 and $4.9 \%$ in the second and third quarters of 2018 (FocusEconomics, 2018). Nonetheless, the forecast shows steady growth ahead for the AEC. In fact, according to the McKinsey Global Institute (MGI) report, ASEAN economies are among the world's outperforming emerging economies with a positive prospect of long-term growth (Das and Lin, 2018). While the economic growth and social progress in the ASEAN region are commendable, it is important to consider the ecological and environmental consequences of it. The literature on the economic growth and environmental degradation is mixed and the focus of a number of studies has been on the contrast between the short and long terms consequences of the economic growth. Specifically, the notion that despite degradation of the environment in the shortrun the economic growth can improve the environmental quality in the long-run. A phenomenon often referred as the Environmental Kuznets Curve $(\mathrm{EKC})^{2}$. However, the empirical evidence on this aspect of economic growth and environment entails mixed findings. For instance, Lindmark (2002), Lantz and Feng (2002), Caviglia-Harris et al (2009), Narayan and Narayan (2010), Song et al (2013), Onafowora and Owoye's (2014), Apergis (2016) and Atasoy (2017) report contrasting results in different countries. One may argue that there could be differences between the developed and developing countries, yet such an assertion would be oversimplification as the empirical evidence suggests that there are considerable differences even within the developed and developing countries (see, Al-Mulali and Ozturk (2016), Özokcu and Özdemir (2017) and Shahbaz et al (2018). Concomitantly, it requires one to conduct an analysis specific to the economies in question before one can draw a conclusion as to the ecological and environmental consequences of economic growth in the ASEAN region.

Parallel to the economic growth, a crucial aspect is the growth of the financial sector or financial development. In fact, the economic and financial growth and stability are logically and legitimately

\footnotetext{
${ }^{2}$ See, Grossman and Krueger (1991) and Shafik (1994) among the initial contributors.
} 
perceived to be two side of a coin (Borio, 2011 and Nasir et al, 2015). The importance of the financial sector for the real economy has been magnified by the Global Financial Crisis of 2008. Although the nexus between the financial and economic stability has been emphasised long ago by various scholars (Bagehot, 1873, Gurley and Shaw (1960), Goldsmith (1969), McKinnon (1973) and Shaw (1973) and Minsky (1974, 1982) Kindleberger, 1978) the GFC revived and reignited the debate on the role of financial development in the economic growth and development (Borio, 2011; Nasir et al 2015). Concomitantly, some scholars argued that the role of the financial sector in the economy should be seen in a more holistic manner (Beck, 2012, Nguyen et al 2017). There is also an important ecological aspect of finance (Grafton et al 2004; Campiglio, 2016; Ackerman, 2017; Leimbach et al 2018; Richardson, 2018; Yuan and Gallagher, 2018). Despite the recognition of financial development as an important factor for the economic growth it is also vital to consider this nexus more broadly and bring into account the social and ecological consequences of financial development which is one of the aspect the subject study is focusing on, specifically in the context of ASEAN region.

Similar to the literature on the finance-growth nexus, the literature on the role of finance in environmental degradation or improvement is also interesting but contrasting and hence inconclusive ( see for instance, Tamazian and Rao, 2010; Ozturk and Acaravci, 2013; Shahbaz et al., 2016a, 2016b; Bekhet et al., 2017; Salahuddin et al., 2018). On this aspect, Zhang (2001) argued that the nexus between financial development and energy consumption can be explained by three channels. According to the first channel, the financial development results in the increase in the FDI and economic growth which consequently leads to an increase in the consumption of energy. Secondly, there is an increase in the credit creation due to efficient financial intermediation which leads to an increase in the usage of energy-intensive goods and services. In the third channel, financial development leads to more investment which also increases the consumption of energy and hence, environmental degradation (Zhang, 2011). Concomitantly, it is worth acknowledging that the finance-environment nexus the finance-led economic growth plays a crucial part. As the evident on the finance-growth nexus suggests that the financial development is a major catalyst of economic growth (Soukhakian, B. (2007), Soukhakian, N. (2007), Katircioglu, 2012), it intuitive to expect that this may have ecological implications. Specifically, real income growth as results of financial development which leads to additional energy demand and investment in energy sector which then affects environment (Katircioglu and Taspinar (2017) and Cetin and Ecevit (2017). On 
the positive side, in a later study, Chang (2015) argued that financial development may offer more opportunities to develop the renewable energy sector by providing more funds to innovative firms. Nonetheless, the technological innovation and efficiency accompanied by FDI can help to reduce the energy consumption. However, we are to see which channel of financial development rolls the roost and specially, whether the financial development leads to improvement or degradation of environment in the under analysis ASEAN region. Nonetheless, we are employing a more inclusive approach to measure the financial development and structure by incorporating not only the credit creation but also the development of equity market and international indebtedness of the underlying economies.

The overarching evidence on the FDI role in environmental degradation is also inconclusive and contrasting. This inconclusiveness and contrast is a manifestation of the fact that theoretically there are three key dimensions of the nexus between FDI and environmental degradation. These include pollution-haven, pollution-halo and scale-effect hypothesis. According to the pollution-haven hypothesis the inwards FDI attracted by the weak regulatory environment in the host country leads to degradation of the environment (Cole and Fredriksson 2009: Naughton, 2014). On the contrary, the pollution-halo hypothesis suggests that FDI by the multinational and transnational enterprises leads to the application of global environmental practices and standards in the host country as well as the transfer of green technology. In a nutshell, whether the FDI decreases or increases the environmental degradation is contingent on whether pollution-haven or pollution-halo factor dominates. Nonetheless, the third aspect of FDI that is scale-effect hypothesis is also too important to condone. In this channel, the FDI leads to a significant increase in the industrial output of the host country which leads to an increase in the pollution and environmental degradations (Pao and Tsai, 2011, Rezza, 2013). Given that the ASEAN countries have been attracting huge influx of FDI and along with the substantial economic growth, the financial sector have also been going through growth and development, it is intriguing to investigate the ecological consequences of these factors. The recent estimates suggest that the FDI flows to the ASEAN have been continuously increasing each year reaching an all-time high of US\$137 billion in 2018 and are also expected to reach US\$200 by 2025 (ASEAN Investment Report, 2018). Keeping this in context, we aimed to analyse the implication of economic growth, FDI and financial development for environmental degradation in ASEAN countries while drawing on the empirical data from 1982 to 2014. In terms of originality and contribution to the existing evidence and debate on the subject, 
the subject study has a) analysed the ecological and environmental implications of rapid economic growth in the ASEAN region, in both short and long run by exploring the aspect of EKC b) the subject study has analysed the ecological and environmental implications of financial development for the ASEAN region while employing a more inclusive approach to financial development which entailed three dimension of financial development and c) the study analyse the ecological and environmental implication of FDI for the ASEAN region which has experienced an unpresented influx of FDI in the recent years. In so doing, we employed a set of quantitative techniques for panel data spanning from 1982 to 2014, including Dynamic Ordinary Least Squares (OLS) (DOLS) and Fully Modified OLS (FMOLS) approaches. Our findings indicate that financial and economic development as well as FDI have a statistically significant long-run co-integrating relationship with environmental degradation ( $\mathrm{CO}^{2}$ emissions) in the under analysis economies. It showed that the in ASEAN-5 countries, the economic growth, financial development and FDI leads to an increase in the environmental degradation. The quadratic term for economic growth showed a negative impact on the environmental degradation i.e. Environmental Kuznets Curve (EKC). Our key findings manifest and emphasise the importance of appropriate policies for more inclusive economic and financial development and sustainable foreign direct investment which does not harbour adverse ecological consequences for the ASEAN economies.

The result of the paper proceeds as follows, in section 2 we briefly reflect and acknowledge the existing evidence on the subject. Section 3 presents the empirical framework and dataset, Section 4 will present the empirical findings which will lead to the conclusion in section 5 .

\section{Literature Review}

This study is focusing on the ecological implication of economic growth, financial development and FDI, concomitantly, for the sake of coherence we can divide the literature into three aspects. To start with we look at the evidence on the economic growth and environmental degradation.

\subsection{Economic Growth and Environment Nexus}

Economic growth is one of the prime objectives of macroeconomic policymaking, particularly since the WWII (Raworth, 2017). The same holds true for the ASEAN economies. Yet, an important aspect which gained global attention in the last few decades is the ecological consequences of economic growth. On this aspect, a number of studies investigated the impact of economic growth on environmental degradation and often focused on the notion of the 
Environmental Kuznets Curve (EKC). According to the EKC, there is an inverted U-shaped relationship between economic growth and environmental degradation and hence, in the short-run, the economic growth contributes to the degradation of the environment,however as the countries reach the higher level of income this relationship goes inverse and economic growth starts to have a positive impact on the environment.Following the initial contribution on the nexus between economic and environment in the context of EKC by Grossman and Krueger (1991) and Shafik (1994), a number of studies have empirically tested this nexus. For example, in their study on the UK, Fosten et al. (2012) reported significant evidence of EKC. Furthermore, they found an asymmetric adjustment of temporary disequilibrium from the long-run $\mathrm{EKC}$ which they associated with the presence of strong environmental regulation in the UK. Perhaps, this is an aspect which could be of interest to the emerging economies such as ASEAN. In another study, Esteve and Tamarit (2012) focusing on the Spanish data argued that although the EKC may not follow a strict inverted U-shaped pattern, there is evidence that in the long run, the economic growth leads to a reduction of $\mathrm{CO} 2$ emissions and hence environmental improvements. However, in a later study which was also focusing on Spain, Sephton and Mann (2013) argued that in fact there is a longrun non-linear attractor that draws emissions and per capita income together and there is also an asymmetric adjustment. Similarly, Tiwari et al. (2013) and Sinha and Shahbaz (2018) reported a short as well as a long-run relationship between economic growth and environmental degradation. However, on the contrary, while focusing on the Indian economy Gosh (2010) reported lack of evidence on the existence of a long run relationship between economic growth and emission. Similarly, Pal and Mitra (2017) analysing Indian as well Chinese data failed to find a significant evidence of EKC, yet on the contrary, Brajer et al (2008) reported significant evidence of EKC in China. There is also a strand of literature which focused on multiple countries. For instance, employing the data of 15 OECD countries ${ }^{3}$, Apergis (2016) reported that although there was overarchingly evidence of EKC, however, it was not the case in all of the countries. Similarly in a study by Sinha et al (2017) reported the presence of rather an N-shaped EKC in N-11 countries ${ }^{4}$. In another study which drew on the panel data from 27 developed countries, Al-Mulali and Ozturk (2016) reported significant evidence of EKC relationship. Similarly, in a study on Arctic countries,

\footnotetext{
${ }^{3}$ These include 14 European countries i.e. Austria, Belgium, Canada, Denmark, Finland, France, Italy, Netherlands, Norway, Portugal, Spain, Sweden, Switzerland, and UK and USA.

${ }^{4} \mathrm{~N}-11$ or Next 11 includes Bangladesh, Egypt, Indonesia, Iran, Mexico, Nigeria, Pakistan, the Philippines, Turkey, South Korea, and Vietnam.
} 
Baek (2015) reported that there was very little evidence of the existence of the EKC in the Arctic countries. In another remarkable study, Onafowora and Owoye's (2014) analysed the notion of EKC in the selected economies of Brazil, China, Egypt, Japan, Mexico, Nigeria, South Korea, and South Africa indicate. However, they could only find the evidence of EKC in Japan and South Korea which were the only developed countries in their dataset. The led Shahbaz et al (2018) argued that the stage of the development of a country may also influence the presence of EKC. However, a study by Narayan and Narayan (2010) focusing on 43 developing countries reported although there was evidence of EKC in the South Asian and Middle Eastern countries, on the whole, there were mixed and contrasting results. This implies that there could be regional heterogeneities as well and hence, one size does not fit all. Perhaps comprehensive studies by Caviglia-Harris et al (2009) on 40 countries and Özokcu and Özdemir (2017) on 52 developing and 26 OECD countries, reported that there is no significant evidence of EKC. They argued that continued economic growth cannot lead to environmental improvement. Similarly, in the most recent studies, Shahbaz and Sinha (2019) conducted an inclusive survey of literate and concluded that the results of EKC are inconclusive and are contingent on the contexts, time period, explanatory factors and choice of empirical approach. These findings are of profound importance for the ASEAN countries and particularly in the context of the remarkable growth they have achieved and projected to achieve in the year ahead.

\subsection{Financial Development and Environment Nexus}

Financial stability is vital for economic stability and by the same logic, a well-functioning and efficient financial sector facilitates economic growth. (Soukhakian, B. (2007), Soukhakian, N. (2007), Katircioglu, 2012), it intuitive to expect that this may have ecological implications. However, the positive role of financial sector development in enhancing economic growth can also increase the consumption of energy and concomitantly have unintended ecological consequences (Sadorsky, 2010, 2011; Shahbaz et al., 2012a, 2012b; Shahbaz et al., 2013c; Islam et al., 2013; Shahbaz et al., 2017c, Katircioglu and Taspinar, 2017; Cetin and Ecevit, 2017; Shahbaz et al 2018). The empirical evidence on the nexus between financial development and environmental degradation is mixed and contrasting. For instance, there are also a number of studies which suggest that the financial sector development can improve environmental quality. Among the earlier contributors, Tamazian et al. (2009) analysing the BRICS economies reported that financial 
development can reduce environmental degradation. Similarly, in their study focusing on 24 transition economies, Tamazian and Rao (2010) reported that financial liberalisation can lead to lowering $\mathrm{CO} 2$ emissions and hence improves environmental quality. Later, studies by Jalil and Feridun (2011) on China, Shahbaz et al. (2013c) on Malaysia and South Africa, Abbasi and Riaz (2016) on Pakistan, Dogan and Seker (2016) on top countries listed in the renewable energy attractiveness index and most recently Shahbaz et al (2018) on France, reported positive ecological contributions of financial development. On the contrary, there are a considerable number of studies which reported that in fact financial development negatively affects the environment by increasing carbon emission. For instance, Zhang (2011) on China, Shahbaz et al. (2013c) on Indonesia, Javid and Sharif (2016) on Pakistan and Salahuddin et al. (2018) on Kuwait reported that the financial development has negative ecological consequences. Interestingly, there are also a considerable number of studies which reported that in fact there is no significant relationship between financial development and environmental degradation. For instance, Ozturk and Acaravci (2013) on Turkey, Omri et al. (2015) on MENA countries, Bekhet et al. (2017) on GCC countries, Charfeddine and Khediri (2016) on UAE and, Çoban and Topcu (2013) on EU countries reported neutral and mixed results. This implies that it will not be cogent to generalise the findings to existing evidence to the subject economies of ASEAN which have also been going through rapid economic and financial development. Keeping that in context, we are analysing the implication of this economic and financial development and its ecological consequences for ASEAN.

\subsection{FDI and Environment Nexus}

The third crucial nexus the subject study is exploring is the nexus between FDI and Environment. In the context of the recent development in the ASEAN region and remarkable increase in the Flows of FDI which are also expected to further increase in the years ahead (ASEAN Investment Report, 2018), it is important to account for the ecological consequences of such huge inflows of FDI for the region. As acknowledged in the beginning of this treatise, theoretically, the FDI can have positive to negative ecological consequences, depending on which transmission channel is

more dominant. Putting it simply, whether, the pollution-haven hypothesis, the pollution-halo hypothesis, and/or the scale effects hypothesis prevails (Pao and Tsai, 2011). The empirical evidence suggests that in different countries and regions, FDI has shown to have different effects on environmental degradation. For instance, Pao and Tsai (2011) on BRICS, Al-mulali and Tang 
(2013) on the GCC countries, Pazienza (2015a an 2015b) on OECD countries, Zhang and Zhou (2016) on the Chinese regions, Liu et al. (2017) and Jiang et al. (2017) on Chinese cities reported that the FDI improves environmental quality. On the contrary, He (2006) and Ren et al. (2014) on China, Hitam and Borhan (2012) and Lau et al. (2014) on Malaysia, Tang and Tan (2015) on Vietnam, paramati et al (2016) on 20 developing countries ${ }^{5}$, Sbia et al (2014) on Middle Eastern countries, Abdouli and Hammami (2017) on MENA, Shahbaz et al. (2015) on high, middle and low-income countries and Solarin et al. (2017) on Ghana and most recently, Shahbaz et al (2018) focusing on France reported that the FDI leads to an increase in environmental degradation. In fact, there are a number of studies which reported insignificant impact, for instance, Kivyiro and Arminen (2014) on selected sub-Saharan countries and Lee (2013) on the G-20 countries. In fact, those studies which focused on some of the countries in the ASEAN region also reported mixed and contrasting results (contrast, Chandran and Tang (2013), Zhu et al (2016), Baek (2016). Nonetheless, they also ignored the important aspect of financial development and economic growth which are required to be seen in conjunction with the FDI. Concomitantly, keeping the financial and economic development in the ASEAN region as well as a remarkable influx of FDI, the subject study is intended to investigate the ecological consequences of these developments. In so doing, we are employing a set of empirical approaches and in the next section we elaborate on them.

\subsection{Methodology}

Firstly, we attempt to evaluate the cross-sectional dependence among variables by following Pesaran $(2004,2007)$. To start with the equation as follows:

$$
\Delta \mathrm{Y}_{\mathrm{it}}=\pi_{\mathrm{i}} \mathrm{Y}_{\mathrm{i}, \mathrm{t}-1}+\gamma_{\mathrm{i}} \mathrm{Z}_{\mathrm{it}}+\sum_{\mathrm{j}=1}^{\mathrm{p}-1} \theta_{\mathrm{ij}} \mathrm{Y}_{\mathrm{i}, \mathrm{t}-\mathrm{j}}+\varepsilon_{\mathrm{it}} \text { (Eq. 1) }
$$

In which, $Z_{i t}$ is a deterministic component and $\sum_{j=1}^{p-1} \theta_{i j} Y_{i, t-j}$ is considered as ADF test. Therefore, $\varepsilon_{i t}$ is cross-sectional for objects i when they share the common factors. By defining that, we have:

$$
\varepsilon_{\mathrm{it}}=\theta_{\mathrm{i}} \mathrm{f}_{\mathrm{t}}+\mathrm{u}_{\mathrm{it}} \text { (Eq. 2) }
$$

$\theta_{i}$ means that each individual has different impact and $u_{i t}$ considers as no cross-sectional and no autocorrelation.

\footnotetext{
${ }^{5}$ Brazil, China, Chile, Czech Republic, Colombia, Egypt, Greece, Hungary, Indonesia, India, Korea, Mexico, Malaysia, Peru, Poland, Philippines, Russia, South Africa, Turkey and Thailand.
} 
By embedding the Equation 2 into Equation 1, we have:

$$
\Delta Y_{i t}=\pi_{i} Y_{i, t-1}+\gamma_{i} Z_{i t}+\sum_{j=1}^{p-1} \theta_{i j} Y_{i, t-j}+\theta_{i} f_{t}+u_{i t} \text { (Eq. 3) }
$$

Thereafter, we follow the Pesaran (2004) to test whether there is an existence of crosssectional dependence among variables or not which is built the hypothesis: $\mathrm{H}_{0}: \theta_{i} \neq 0$ and $\mathrm{H}_{\mathrm{A}}$ : $\theta_{i}=0$.

Secondly, we elaborate on the test of stationarity based on Levin-Lin-Chu (2002), ImPesaran-Shin (2003) and Pesaran (2007). The general equation built by Levin-Lin-Chu (2002) test can be specified as follows:

$$
\Delta Y_{i t}=\pi_{i} Y_{i, t-1}+\gamma_{i} Z_{i t}+u_{i t} \text { (Eq. 4) }
$$

In which, $\mathrm{u}_{\mathrm{it}}$ is white noise, then $\mathrm{u}_{\mathrm{it}} \sim N\left(0 ; \sigma^{2}\right)$. Then, the hypothesis for the equation 4 having a unit root test against that $\mathrm{Y}_{\mathrm{t}}$ is stationary. So, $\mathrm{H}_{0}: \pi_{i} \neq 0$ and $\mathrm{H}_{\mathrm{A}}: \pi_{i}<0$. The test of Levin-Lin-Chu (2002) had been used to estimate the Augmented Dickey-Fuller regression on the pooled panel data by Ordinary Least Squares. However, the Im-Pesaran-Shin (2003) develops the latter assumption, which corrects the drawbacks from the OLS approach by using varying autoregressive procedures across estimated individuals. Therefore, the results are known as groupmean of individual t-statistics with the following equation where $\mathrm{i}=1,2, \ldots \mathrm{N}$ and $\mathrm{t}=1,2 \ldots \mathrm{T}$ from the previous equation 4 .

$$
\overline{\mathrm{t}}_{\mathrm{it}}=\mathrm{i}^{-1} \sum_{\mathrm{i}=1}^{\mathrm{N}} \mathrm{t}_{\mathrm{iT}}\left(\pi_{\mathrm{i}}, \theta_{1 \mathrm{i}}, \ldots, \theta_{\mathrm{iP}}\right) \quad \text { (Eq. 5) }
$$

Thereafter, we extract the terms of $\left(\pi_{i}, \theta_{1 i}, \ldots, \theta_{\mathrm{iP}_{\mathrm{i}}}\right)$ denotes the $\mathrm{t}$-statistics for testing the unit root for the $\mathrm{i}^{\text {th }}$ individual procedures (in which $\pi_{\mathrm{i}}$ - lagged order, normally used to select optimal lag order). Therefore, $\overline{\mathrm{t}}_{\mathrm{it}}$, which represents Im-Pesaran-Shin (2003) test, is able to test the null hypothesis $\mathrm{H}_{0}: \pi_{i} \neq 0 \forall i$ against $\mathrm{H}_{\mathrm{A}}: \exists i \in\{1, \ldots, N\}, \pi_{i}<0$. Subsequently, for the existence of cross-sectional dependency, the CIPS (Cross-sectional IPS) is developed on the basis of Im Pesaran-Shin (2003). When IPS employs ADF, CIPS it uses cross-sectional ADF (called by CADF). The main concept of CIPS is to add the lagged cross-sectional value of mean of the individual $\bar{Y}_{t}$ to control the effects of the common factors. Hence, CIPS is quite popular to use for 
the existence of cross-sectional dependence. The other process of CIPS is similar to IPS except the existence of means of $\bar{Y}_{t}$ as the specific factors for cross-sectional dependency.

Thirdly, we will discuss the methodologies used for testing whether the co-integration in panel data exists or not. The approach from co-integration test for panel data is mainly based on the following notion:

$$
y_{i t}=x_{i t}^{\prime} \beta_{i}+z_{i t}^{\prime} \gamma_{i}+e_{i t} \quad(\text { Eq. 6) }
$$

The test is focused on the covariates in $x_{i t}$ are not co-integrated themselves. $\beta_{i}$ denotes the vector conveying the co-integrating phenomenon, which might differ across panels. $\gamma_{\mathrm{i}}$ is a vector with coefficients on $\mathrm{Z}_{\mathrm{it}}$, which is known as deterministic terms to control panel-specific effects and linear time trends. $e_{i t}$ is error term, which should be in accordance with white noise $\mathrm{e}_{\text {it }} \sim N\left(0 ; \sigma^{2}\right)$.

Kao (1999) indicates the assumptions of co-integrating vector from Equation 6 with $\beta_{i}=$ $\beta$; therefore, the panels follow common slope coefficients. Thus, Kao (1999) proposes five kinds of test such as Modified Dickey-Fuller t, Dickey-Fuller t, Augmented Dickey-Fuller t, Unadjusted modified Dickey-Fuller $t$ and Unadjusted Dickey-Fuller $t$ from the Dickey-Fuller regression:

$$
\hat{\mathrm{e}}_{i t}=\rho \hat{\mathrm{e}}_{\mathrm{i}, \mathrm{t}-1}+\mathrm{v}_{\mathrm{it}} \quad \text { (Eq. 7) }
$$

In which, $\rho$ is the common Auto Regression parameter of the estimated residuals. Meanwhile, the Augmented Dickey-Fuller regression is given by

$$
\hat{\mathrm{e}}_{\mathrm{it}}=\rho \hat{\mathrm{e}}_{\mathrm{i}, \mathrm{t}-1}+\sum_{j=1}^{p} \rho_{j} \Delta \hat{\mathrm{e}}_{\mathrm{i}, \mathrm{t}-\mathrm{j}}+\mathrm{v}_{\mathrm{it}}
$$

Interestingly, in this approach, $\rho$ reflects the number of lagged difference terms. Noticeably, the asymptotic distribution for all Kao (1999) tests must be converged into $\mathrm{N}(0,1)$. In contrast, Pedroni (1999) evaluates each panel-specific co-integrating vector from Equation 6 has different individual slope coefficients. Then, the Pedroni (1999) test employs the unit root test of estimated residuals by Augmented Dickey-Fuller regression. However, the interesting thing is to allow each $\rho_{i}$ instead of the same $\rho$ (like Kao (1999)). In addition, this approach is considered to be following the convergence characteristics after appropriate standardization. Another cointegration test is employed by Westerlund (2005), which assumes that the specific co-integrating vectors have different individual slope coefficients. This test allows to perform well under the cross-sectional dependency and it is usually used as a robustness test. Additionally, Westerlund 
(2005) is normally used to deal with the problem raising by determining structural breaks endogenously.

Finally, many previous studies proposed that the presence of co-integration should be referred to the two main methods such as OLS-based estimators-FMOLS (Fully Modified OLS) and DOLS (Dynamics OLS). The main difference between the two approaches is how to correct the autocorrelation in regression. FMOLS allows using Newey-West for correction whereas DOLS accepts to add more lagged and lead variables. Pedroni (1996, 2001) suggested the approach to estimate the coefficients, which is used to measure the long-run effects.

$$
\widehat{\beta}_{\text {FMOLS }}=\left(\sum_{\mathrm{i}=1}^{\mathrm{N}} \hat{\mathrm{L}}_{22 \mathrm{i}}^{-1} \sum_{\mathrm{t}=1}^{\mathrm{T}}\left(\mathrm{x}_{\mathrm{it}}-\overline{\mathrm{x}}_{\mathrm{i}}\right)^{2}\right)^{-1} \sum_{\mathrm{i}=1}^{\mathrm{N}} \hat{\mathrm{L}}_{11 \mathrm{i}}^{-1} \hat{\mathrm{L}}_{22 \mathrm{i}}^{-1}\left(\sum_{\mathrm{t}=1}^{\mathrm{T}}\left(\mathrm{x}_{\mathrm{it}}-\overline{\mathrm{x}}_{\mathrm{i}}\right) \mathrm{y}_{\mathrm{it}}^{*}-\mathrm{T} \widehat{\delta}_{1}\right)
$$

In which,

$$
y_{i t}^{*}=\left(y_{i t}-\bar{y}_{i}\right)-\left(\frac{\hat{L}_{21 i}}{\hat{L}_{22 i}}\right) \Delta x_{i t}+\left(\frac{\hat{L}_{21 i}-\hat{L}_{22 i}}{\hat{L}_{22 i}}\right) \beta\left(x_{i t}-\bar{x}_{i}\right)
$$

and we denotes $\widehat{\delta_{1}}$ as

$$
\widehat{\delta}_{1} \equiv \widehat{\Gamma}_{21 \mathrm{i}}+\widehat{\Omega}_{21 \mathrm{i}}^{0}-\left(\frac{\widehat{\mathrm{L}}_{21 \mathrm{i}}}{\widehat{\mathrm{L}}_{22 \mathrm{i}}}\right)\left(\widehat{\Gamma}_{22 \mathrm{i}}+\widehat{\Omega}_{22 \mathrm{i}}^{0}\right)
$$

In order to clarify, we refer to $\Omega$ as asymptotic covariance matrix for long-run variance and $\Gamma$ as dynamic covariance. In addition, $\mathrm{L}$ is a lower triangular matrix with partition calculation. Then, DOLS estimator is employed which takes the following form:

$$
y_{i t}=\beta_{i}^{\prime} x_{i t}+\sum_{j=-q}^{q} \zeta_{i j} \Delta x_{i, t+j}+\gamma_{l i} D_{l i}+\varepsilon_{i t} \quad \text { (Eq. 12) }
$$

In which, q is known as the numbers of leads/lags chosen for the models. Thereafter, DOLS estimator is referred to Kao and Chiang (2001) for using the finite sample properties.

\subsection{Data}

In this study, we choose five ASEAN countries which are also the largest economies of the ASEAN block. These include Singapore, Thailand, Malaysia, Philippines and Indonesia over the period from 1982 to 2014 . The main reason to focus on these economies and the time period of 33 years is data availability from the World Bank and well-balanced data for cross-sectional with time-series data characteristics. There are seven variables used in this study and the description as well as sources of data are represented in Table 1 below. 


\begin{tabular}{|c|c|c|c|}
\hline Variables & Explanation & Measurement & Source \\
\hline $\mathrm{CO}_{2}$ & $\begin{array}{l}\mathrm{CO}_{2} \text { emissions } \\
\text { (metric tons per } \\
\text { capita) }\end{array}$ & $\begin{array}{l}\text { The amount of carbon dioxide } \\
\text { emissions was calculated under the } \\
\text { procedure of stemming from burning } \\
\text { fossil fuel including solid, liquid, and } \\
\text { gas fuels and gas flaring. }\end{array}$ & $\begin{array}{l}\text { World } \\
\text { Development } \\
\text { Indicators }\end{array}$ \\
\hline FDI & $\begin{array}{l}\text { Foreign direct } \\
\text { investment, net } \\
\text { inflows } \\
\text { (percentage of } \\
\text { Gross Domestic } \\
\text { Product) }\end{array}$ & $\begin{array}{l}\text { There were net inflows computing by } \\
\text { new investment inflows excluding } \\
\text { disinvestment. This figure was divided } \\
\text { by the total Gross Domestic Product }\end{array}$ & $\begin{array}{l}\text { World } \\
\text { Development } \\
\text { Indicators }\end{array}$ \\
\hline GDP & $\begin{array}{l}\text { The annual } \\
\text { percentage } \\
\text { growth rate of } \\
\text { GDP at market } \\
\text { prices based on } \\
\text { constant local } \\
\text { currency. }\end{array}$ & $\begin{array}{l}\text { GDP is the sum of gross value added by } \\
\text { all resident producers in the economy } \\
\text { plus any product taxes and minus any } \\
\text { subsidies not included in the value of the } \\
\text { products. Then we calculate the growth } \\
\text { rate from the previous year. }\end{array}$ & $\begin{array}{l}\text { World } \\
\text { Development } \\
\text { Indicators }\end{array}$ \\
\hline \multicolumn{4}{|c|}{ Financial development and Structure Dataset are measured by a group of variables here } \\
\hline $\mathrm{BCBD}$ & $\begin{array}{l}\text { Bank credit to } \\
\text { Bank Deposit } \\
\text { (Percentage) }\end{array}$ & $\begin{array}{l}\text { Private credit was retrieved by deposit } \\
\text { money banks report; specifically, IFS } \\
\text { line 22d, FOSAOP over the bank } \\
\text { deposits was extracted from IFS lines } \\
\text { 24, FOST, and 25, FOSD. }\end{array}$ & $\begin{array}{l}\text { Čihák et al. } \\
\text { (2012) } \\
\text { The World } \\
\text { Bank }^{6} \\
\text { International }^{\text {Monetary Fund }}{ }^{7}\end{array}$ \\
\hline Listco_pc & $\begin{array}{l}\text { The number of } \\
\text { listed companies } \\
\text { per } 10.000 \\
\text { population }\end{array}$ & $\begin{array}{l}\text { Total number of listed companies was } \\
\text { scaled by } 10.000 \text { population }\end{array}$ & $\begin{array}{l}\text { World } \\
\text { Development } \\
\text { Indicators }\end{array}$ \\
\hline Int. Debt & $\begin{array}{l}\text { International } \\
\text { debt issued over } \\
\text { total Gross } \\
\text { Domestic } \\
\text { Product }\end{array}$ & $\begin{array}{l}\text { The amount of outstanding of } \\
\text { International Debt Securities was } \\
\text { divided by total Gross Domestic } \\
\text { Product }\end{array}$ & $\begin{array}{l}\text { Bank for } \\
\text { International } \\
\text { Settlements } \\
\text { World } \\
\text { Development } \\
\text { Indicators } \\
\end{array}$ \\
\hline
\end{tabular}

(Source: The author's collection)

\footnotetext{
${ }^{6}$ World Bank in Washington District of Columbia

${ }^{7}$ International Monetary Fund in Washington District of Columbia
} 
For financial development, we took an inclusive approach. We chose three categories such as bank credit to bank deposit, the number of listed companies and international debt representing financial development and structure dataset. These are the components for the banking system, equity market and debt market, which reflect the ability for financial integration and development by each country. After data collection, we transformed the absolute value to the percentage change for each country. These five economies are supposed to advance and emerging economies, which is attracting scholars' attention.

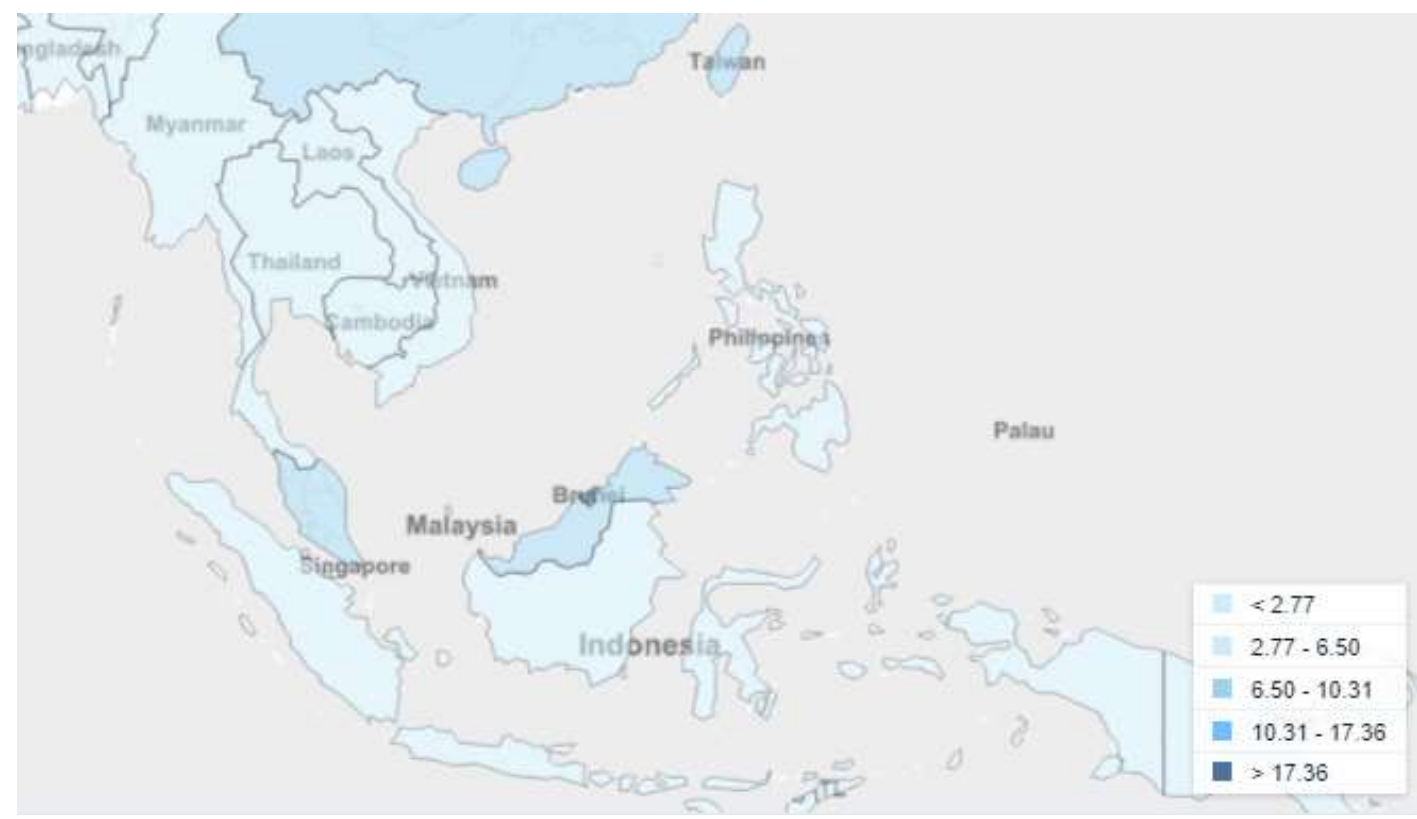

Figure 1. CO2 emission in the ASEAN region by World Bank Data Sources

(Source: World Development Indicators)

The figure 1 summarises the $\mathrm{CO} 2$ emission in the ASEAN region by World Bank Data Sources. In which, Malaysia is the country which lies into the group from 6.5 to 10.31 metric ton carbon dioxide in the ASEAN area. The remaining ones are categorized into one group with 2.77 -6.50 metric ton.

\subsection{Descriptive Statistics}

In order to gain some insight into the characteristics of the dataset, we performed the descriptive statistics analysis as presented in Table 2.

Table 2. Descriptive statistics

\begin{tabular}{cccccc}
\hline Variable & Mean & Std. Dev. & Skewness & Kurtosis & J-B \\
\hline $\mathrm{CO}_{2}$ & 0.034753 & 0.125603 & 1.020753 & 10.67684 & $433.8^{* * *}$
\end{tabular}




$\begin{array}{cccccc}\text { FDI } & -0.12543 & 4.769969 & -8.031189 & 91.36219 & 55000 * * * \\ \text { GDP } & -0.29684 & 2.852479 & -4.577124 & 45.89052 & 13000 * * * \\ \text { BCBD } & -0.00248 & 0.086582 & -0.7608297 & 8.23216 & 204.1 * * * \\ \text { Listco_pc } & 0.071519 & 0.348047 & 8.136386 & 84.77175 & 48000 * * * \\ \text { Int. Debt } & 0.127683 & 0.417534 & 2.527964 & 10.59441 & 572.3 * * *\end{array}$

This table reports the summary statistics including mean, standard deviation (Std. Dev.), skewness, excess kurtosis, and Jarque-Bera $(\mathrm{J}-\mathrm{B})$ test. The symbols *, **, and *** denote the significance at the 10\%, 5\%, and $1 \%$ levels, respectively.

Based on the descriptive statistics, the value of skewness for all variables is positive and excess from zero. Hence, all variables are demonstrated the characteristics for skewness to the right. In addition, the excess kurtosis is greater than zero, implying that all variables' distributions experience the fat-tailed phenomenon. From the skewness and kurtosis findings, all variables are rejected to be normally distributed. The Jarque-Bera test subsequently confirmed the results. These findings support the notion to employ the set of quantitative techniques as manifested in the next section.

\subsection{Empirical Findings}

\subsection{Panel Unit Root Test}

Before the application of panel unit tests for stationarity of the variables, we tested whether a cross-sectional dependency exists or not. In so doing, we employ the Breusch-Pagan LM (1980), Pesaran (2004) and Frees $(1995,2004)$ tests and the results are in the following Table 3.

Table 3. Cross-section dependence tests

\begin{tabular}{|c|c|c|}
\hline Test & parameter & Results \\
\hline Breusch-Pagan LM & 14.623 & Fail to reject null hypothesis \\
\hline Pesaran & $1.724^{*}$ & Reject at significance level $10 \%$ \\
\hline Frees' test & 0.080 & Fail to reject null hypothesis \\
\hline
\end{tabular}


only the Pesaran (2004) approach rejects this null hypothesis at a significance level 10\% whereas Breusch-Pagan LM (1980) fails to reject. Then, using Frees' Q-distribution (T-asymptotically distributed) based on the approach proposed by Frees $(1995,2004)$ also failed to reject the null hypothesis. Meanwhile, the Pesaran test is mainly based on standard normal distribution. With the analysis above, we evaluate that there is no cross-sectional dependence. Nevertheless, in order to be strongly convinced, we employ both the first and second-generation test for panel unit root tests, which might provide inferences that are more reliable. Basically, we employ multiple panel unit root tests to check whether our variables are stationary or not. These include Levin-Lin-Chu (2002), Im-Pesaran-Shin (2003) and Pesaran panel unit root test in the presence of cross-section dependence by Pesaran (2007). These approaches are abbreviated by LLC, IPS and CIPS, respectively. Although we pass through the cross-sectional dependency, we choose to consider for both cases.

Table 4. Unit root tests

\begin{tabular}{ccccc}
\hline Variable & Test & Intercept & Intercept and Trend & Conclusion \\
\hline \multirow{3}{*}{$\mathrm{CO}_{2}$} & LLC & $-4.9030^{* * *}$ & $-3.9189 * * *$ & Stationary at \\
& IPS & $-6.5278^{*} * *$ & $-6.8139 * * *$ & significance level \\
& CIPS & $-4.942 * * *$ & $-5.168 * * *$ & $1 \%$ \\
\hline \multirow{3}{*}{ FDI } & LLC & $-4.6187 * * *$ & $-4.0224 * * *$ & Stationary at \\
& IPS & $-6.8589 * * *$ & $-7.2387 * * *$ & significance level \\
& CIPS & $-4.911 * * *$ & $-5.158^{*} * *$ & $1 \%$ \\
\hline \multirow{3}{*}{ GDP } & LLC & $-7.4287 * * *$ & $-6.3610 * * *$ & Stationary at \\
& IPS & $-7.0490 * * *$ & $-7.2209 * * *$ & significance level \\
& CIPS & $-5.752 * * *$ & $-5.804 * * *$ & $1 \%$ \\
\hline \multirow{3}{*}{ BCBD } & LLC & $-5.1850 * * *$ & $-4.4493 * * *$ & Stationary at \\
& IPS & $-2.6765 * * *$ & $-2.9133 * * *$ & significance level \\
& CIPS & $-2.715 * * *$ & $-2.896 * *$ & $1 \%$ \\
\hline \multirow{2}{*}{ Listco_pc } & LLC & $-3.9101 * * *$ & $-3.5697 * * *$ & Stationary at \\
& IPS & $-4.7903 * * *$ & $-5.2802 * * *$ & significance level \\
& CIPS & $-3.881 * * *$ & $-3.915 * * *$ & $1 \%$ \\
\hline \multirow{2}{*}{ Int. Debt } & LLC & $-3.8427 * * *$ & $-2.6557 * * *$ & Stationary at \\
& IPS & $-6.4860 * * *$ & $-6.3764 * * *$ & significance level \\
& CIPS & $-5.148 * * *$ & $-5.057 * * *$ & $1 \%$ \\
\hline
\end{tabular}

The symbols *, **, and *** denote the significance at the 10\%, 5\%, and 1\% levels, respectively. A Levin-Lin-Chu unit-root test, $H_{0}$ : Panels contain unit roots and $H_{A}$ : Panels are stationary. As regards Im-Pesaran-Shin unit-root test, $H_{0}$ : All panels contain unit roots (or all the series are non-stationary) and $H_{A}$ : Some panels are stationary. Regarding Pesaran Panel Unit Root Test with cross-sectional, $H_{0}$ : homogeneous non-stationary $($ bi $=0$ for all $i)$; and $H_{A}$ : stationary. 
With the strict assumption and a broad set of tests from LLC, IPS and CIPS, all variables are stationary at significance level $1 \%$. Whether the presence of cross-sectional dependency exists or not, the findings in Table 4 assure that all panels have stationarity.

\subsection{Co-integration Analysis}

In order to provide the co-integration analysis, we employ the Pedroni $(1999,2004)$ test to answer whether there is the existence of panel co-integration among our variables. The null hypothesis postulates that there is no co-integration in all tests.

Table 5. Panel co-integration tests by Pedroni $(1999,2004)$

\begin{tabular}{lcc}
\hline Test-Statistics & Intercept & Intercept and Trend \\
\hline Modified Phillips-Perron & -0.2944 & 0.4553 \\
Phillips-Perron & $-7.4660 * * *$ & $-7.5192 * * *$ \\
Augmented Dickey-Fuller & $-7.6316^{* * *}$ & $-7.3770 * * *$ \\
\hline
\end{tabular}

The symbols *,**, and $* * *$ denote the significance at the $10 \%, 5 \%$, and $1 \%$ levels, respectively. Null hypothesis is no co-integration between variables.

In Table 5 above, the majority of tests indicate rejection of the null hypothesis. This implies the presence of co-integration for both cases i.e. intercept as well as intercept and trend in the panel. We employ Kao (1999) test of no co-integration between a group of variables such as Co2, FDI, GDP, BCBD, Listco_pc and Int. Debt.

Table 6. Panel co-integration tests by Kao (1999)

\begin{tabular}{lcc}
\hline \multicolumn{1}{c}{ Test-Statistics } & Intercept & $\begin{array}{c}\text { Subtract cross- } \\
\text { sectional means }\end{array}$ \\
\hline Modified Dickey-Fuller & $-19.0069^{* * *}$ & $-15.7540 * * *$ \\
Dickey-Fuller & $-11.2485 * * *$ & $-11.1549 * * *$ \\
Augmented Dickey-Fuller & $-9.3509 * * *$ & $-9.4790 * * *$ \\
Unadjusted modified Dickey-Fuller & $-20.1251^{* * *}$ & $-20.4243 * * *$ \\
Unadjusted Dickey-Fuller & $-11.2720 * * *$ & $-11.4651 * * *$ \\
\hline
\end{tabular}

The symbols $*, * *$, and $* * *$ denote the significance at the $10 \%, 5 \%$, and $1 \%$ levels, respectively. $\mathrm{H}_{0}:$ No co-integration and $H_{A}$ : All panels are co-integrated

It is clearly seen that all tests following the Kao (1999) approach unanimously reject the null hypothesis of no cointegration. Therefore, we can conclude that there is co-integration phenomenon in our research variables. This finding is of high significance and provides strong evidence that the variables have a long run relationship.

A point to acknowledge at this juncture is that study by Hossfeld (2010, p.16) indicates that it is necessary to test robustness if the different test by Pedroni $(1999,2004)$ generates different test statistics for the same test decision. The rationale of doing so comes from Monte Carlo 
simulations, which show various test-statistics relying on panel dimension and the assumed data generating process. It is very important to provide additional co-integration testing which proves the robustness for structural breaks and cross-sectional dependence. One of the reliable tests is Westerlund (2005) with the null hypothesis being no co-integration for all panels.

Table 7. Westerlund Panel co-integration tests

\begin{tabular}{cc}
\hline Test statistics & Value \\
\hline $\mathrm{Gt}$ & $-3.928 * * *$ \\
$\mathrm{Ga}$ & -14.139 \\
$\mathrm{Pt}$ & $-9.097 * * *$ \\
$\mathrm{~Pa}$ & $-16.509 * *$
\end{tabular}

The symbols *, **, and *** denote the significance at the 10\%, 5\%, and 1\% levels, respectively. The Ga and Gt test statistics are to test $H_{0}: a_{i}=0$ for all $i$ whereas the $H_{A}: a_{i}<0$ for at least one $i$. In addition, the $P_{a}$ and $P_{t}$ test statistics implying pool information over all the cross-sectional units with $H_{0}: a_{i}=0$ for all $i$ whereas the $H_{A}: a_{i}<0$ for at least one $i$.

The results of Westerlund's tests presented in Table 7 suggest that based on the critical values generating from bootstrapped robust, there are three out of four tests which reject the null hypothesis. These findings further confirm that there is a long-run relationship among variables based on cointegration.

\subsection{Estimation}

We choose two methodologies such as FMOLS (Fully Modified OLS) and Pooled-Mean Group (PMG) for estimating the long-run relationships for our variables. We choose FMOLS as our main approach because FMOLS employs the Newey-West to correct the autocorrelation of the error term $\mathrm{U}_{\text {it. }}$ However, if we choose lagged variables and lead variables in our models to control the errors of autocorrelation on the error term $U_{i t}$, we have the choice of Dynamic OLS.

Table 8. Estimation of co-integrating relationship by FMOLS (trend and non-trend)

\begin{tabular}{ccc}
\hline Estimation method: & \multicolumn{2}{c}{ Fully Modified OLS } \\
\cline { 2 - 3 } Long-run coefficient & Trend & No-trend \\
\hline \multirow{2}{*}{ FDI } & -0.01 & -0.01 \\
& {$[-2.26]$} & {$[2.30]$} \\
GDP & $0.01^{* *}$ & $0.01^{* *}$ \\
& {$[2.25]$} & {$[2.20]$} \\
BCBD & $0.26^{* * *}$ & $0.26^{* * *}$ \\
& {$[6.25]$} & {$[6.23]$} \\
Listco_pc & $0.17^{* * *}$ & $0.18^{* * *}$ \\
& {$[2.97]$} & {$[2.77]$} \\
Int. Debt & -0.01 & -0.01 \\
& {$[-1.48]$} & {$[-1.96]$} \\
\hline
\end{tabular}


The symbols *, **, and $* * *$ denote the significance at the 10\%, 5\%, and 1\% levels, respectively whereas $t$-statistics of the corresponding coefficients are reflected in square brackets.

For both cases of trend and no-trend, there are three significant variables such as GDP, Bank credit (BCBD) and listed companies as a percentage of the population (listco_pc) which positively influence (at $5 \%$ and $1 \%$ significance level) the $\mathrm{CO}_{2}$ emissions in five ASEAN economies. Hence, more financial development implies more carbon dioxide emissions. The credit creation in specific shows that a $1 \%$ change in bank credit over bank deposit, on average, results in a $0.26 \%$ change in the level of carbon dioxide emission for our chosen economies in ASEAN. Moreover, it is also interpreted in the light of results that a $1 \%$ increase in the number of listed leads to the $0.17 \%$ and $0.18 \%$ increase in $\mathrm{CO}_{2}$ emission with and without trend approaches, respectively. Additionally, the results apparently indicate the existence of the long-term cointegration relationship between $\mathrm{CO}_{2}$ emissions and economic growth (GDP) that is also statistically significant. When the GDP rises $1 \%$, which only contributes to a $0.01 \%$ increase in $\mathrm{CO}_{2}$ emission. Noticeably, the GDP growth causes the level of $\mathrm{CO}_{2}$ emission less than the financial development does, which prima facie evident in the magnitude of coefficients.

Table 9. Estimation of co-integrating relationship by DOLS

\section{Estimation method:}

Long-run coefficient by Dynamic OLS

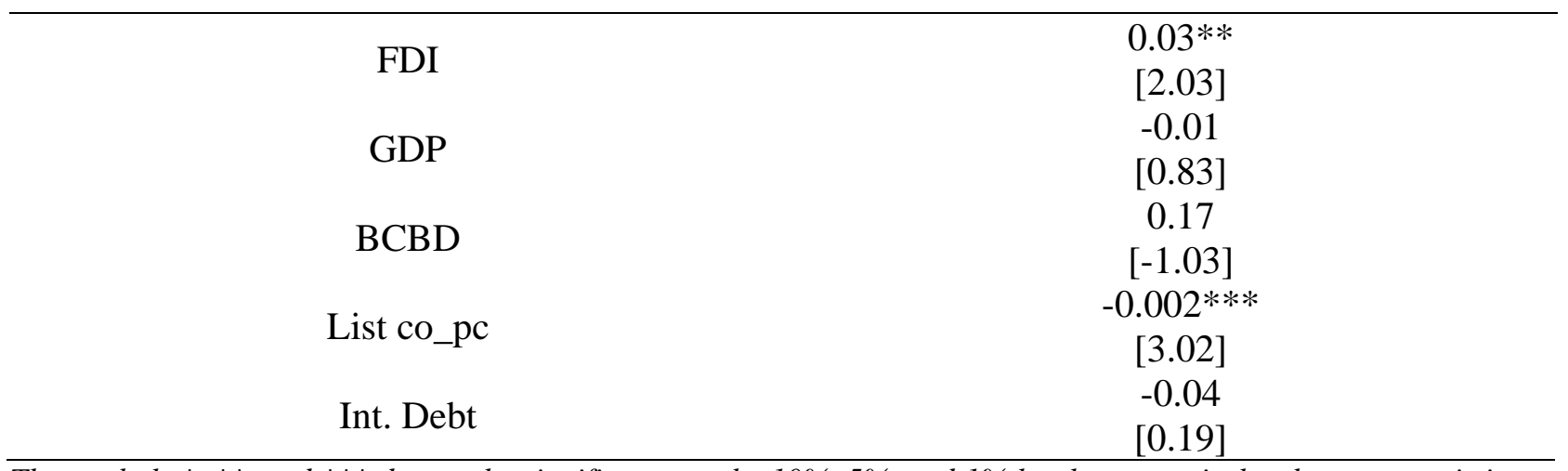

The symbols *,**, and $* * *$ denote the significance at the 10\%, 5\%, and 1\% levels, respectively whereas t-statistics of the corresponding coefficients are reflected in square brackets.

The application of Dynamic OLS yielded results which were different from those obtained by the Fully Modified OLS. The 'FDI' is turned out to be a major factor causing $\mathrm{CO}_{2}$ emission at significance level 5\%. Specifically, it showed that a $1 \%$ increase in FDI will cause $0.03 \%$ increase in $\mathrm{CO}_{2}$ emission. This finding is quite reasonable because foreign direct investment 
is expected to contribute to the level of carbon dioxide by building many plants as well as factories in the ASEAN region. Another considerable estimation is the number of listed companies, it showed negative impact implying that financial development through equity market proves to be more environmentallyly friendly as it decreases $\mathrm{CO}_{2}$ emission. Specifically, if the number of listed companies increases by $1 \%$, the $\mathrm{CO}_{2}$ emission will decrease by $0.002 \%$ at $1 \%$ level of significance. This finding is in contrast to the previous estimation by Fully Modified OLS. The main reason for this difference is a method to solve autocorrelation by using lagged and lead variables. The parameters generated by OLS differ from the ones of FMOLS estimator because the requirements of DOLS is no initial estimation and non-parametric correction. Therefore, Kao and Chiang (2001) indicate that DOLS outperforms FMOLS approach. Not only is DOLS computationally simpler but it also avoids biased errors better than FMOLS. Hence, by employing this methodology, we can investigate the existence of a relationship between FDI and $\mathrm{CO}_{2}$ emission.

\subsection{Estimation of Environmental Kuznets curve}

In order to analyse the long run impact of economic growth on environmental degradation, we add the quadratic of GDP i.e. GDP ${ }^{2}$. Table 10 here shows the relationship by two different methodologies in long-run estimation including FMOLS and DOLS.

\section{Table 10: Environmental Kuznets Curve, FMOLS \& DOLS Estimation}

\begin{tabular}{ccc}
\hline Estimation method: & \multicolumn{2}{c}{ Estimation } \\
\cline { 2 - 3 } Long-run coefficient & FMOLS & DOLS \\
\hline \multirow{2}{*}{ FDI } & -0.01 & 0.04 \\
& {$[-2.42]$} & {$[0.52]$} \\
GDP & -0.0009 & -0.0009 \\
& {$[-5.51]$} & {$[0.48]$} \\
GDP & $0.01 * * *$ & $0.02 * *$ \\
& {$[2.95]$} & {$[1.86]$} \\
BCBD & $0.19 * * *$ & 0.09 \\
& {$[4.60]$} & {$[-0.87]$} \\
Listco_pc & $0.19 * * *$ & $-0.22 * * *$ \\
& {$[3.09]$} & {$[4.01]$} \\
Int. Debt & -0.01 & $-0.13 * *$ \\
\end{tabular}

The symbols $*, * *$, and $* * *$ denote the significance at the 10\%, 5\%, and 1\% levels, respectively whereas $t$-statistics of the corresponding coefficients are reflected in square brackets.

The rest of the results are similar to the previous findings in the model without quadratic of GDP. It showed that one per cent increase in GDP will trigger $0.01 \%$ (at $1 \%$ significance level) 
and $0.02 \%$ (at $5 \%$ significance level) in $\mathrm{CO}_{2}$ emission by Fully Modified OLS and Dynamic OLS respectively. In the FMOLS model, the ratio of bank credit and bank deposit have a positive relationship with $\mathrm{CO}_{2}$ emission at $1 \%$ significance level. Similarly, the number of listed companies are contrasted in two different methodologies. This shows a positive coefficient in FMOLS whereas the coefficient in DOLS is negative. Both cases are significant at 1\%. More interestingly, the international debt is a new finding in this model. This factor generates the negative coefficient in DOLS at significance level of 5\%. This means that one per cent increase in international debt will decrease by $0.13 \%$ in the level of carbon dioxide emission in significance level of $5 \%$. Most

importantly, the coefficients of $\mathrm{GDP}^{2}$ is showed a negative sign indicating the presence of the Environmental Kuznets curve, however, the results were not statistically significant. This implied that the continued economic growth in the ASEAN in its own steam shall be expected to harbour environmental improvements.

\subsection{Robustness Test (white noise test for residuals)}

Considering that fact that there are some contrasting results (signs of 'Listco_pc') in different models, we decided to test the validity and robustness of our model. Thus, we extract the residuals in all the long-term relationships and test for white noise to ensure that our model is not spurious.

Table 11. White noise test for residuals

\begin{tabular}{|c|c|c|}
\hline Models & White noise test statistics & Results \\
\hline $\mathrm{CO}_{2}$ emission (fdi, gdp, bcbd, & 48.6358 & Fail to reject \\
\hline listco_pc, intldebt) by FMOLS & & Residual is white noise \\
\hline $\mathrm{CO}_{2}$ emission (fdi, gdp, bcbd, & 22.9067 & Fail to reject \\
\hline listco_pc, intldebt) by DOLS & & Residual is white noise \\
\hline $\mathrm{CO}_{2}$ emission (fdi, gdp2, gdp, bcbd, & 27.6095 & Fail to reject \\
\hline listco_pc, intldebt) by FMOLS & & Residual is white noise \\
\hline $\mathrm{CO}_{2}$ emission (fdi, gdp2, gdp, bcbd, & 48.2601 & Fail to reject \\
\hline listco_pc, intldebt) by DOLS & & Residual is white noise \\
\hline
\end{tabular}


Based on the results of the white noise test for each model, we can hereby confirm that all of the residuals are white noise with iid $\left(0, \sigma^{2}\right)$. Therefore, our regression results are unbiased and consistent and the model is not spurious. The empirical results lead us to conclude.

\section{Conclusion \& Policy Implications}

In the last few decades in general, and particularly since the Global Financial Crisis, the emerging economies from Asia have acted as a locomotive of global growth. In this context, the ASEAN region has emerged as a crucial player with rapid economic and financial growth as well as attracting an unprecedented inflow of foreign direct investment. While these economic and financial developments are appreciable in the monetary sense, it is cogent to look at the ecological consequence of these factors for the emerging ASEAN. Contextualising on these backgrounds and motivating factors in this study we analysed the ecological implication of the economic growth, financial development and FDI for the ASEAN economies. In this endeavour, we drew on the historical dataset from 1982 to 2014 and employed a broad set of quantitative techniques for panel analysis which entailed Dynamic Ordinary Least Squares (DOLS) and Fully Modified OLS (FMOLS) approaches. Our results perspicuously demonstrate the existence of a statistically significant long-term relationship between $\mathrm{CO}_{2}$ emission and foreign direct investment, gross domestic product, financial development (bank credit over bank deposit and the number of listed companies in equity markets). The only aspect of financial development where we could not find significant ecological implication was international debt which did not show a strong relationship with carbon dioxide emission. This was intuitive and cogent and implied that the domestic credit creation is rather more influential on the environmental degradation in the long run.

Our empirical results also lead us to conclude that the economic growth and increase in the FDI leads to an increase in the environmental degradation in the ASEAN economies. Hence, the rapid economic growth and foreign direct investment which has been observed in the last few decades and expected to continue will have negative ecological consequences. There is significant evidence of Pollution Heaven Hypothesise (PHH). There is also evidence of Environmental Kuznets Curve (EKC) in the ASEAN economies as the quadratic term for GDO was found to have a negative impact. However, the results were not statistically significant implying that the continuous growth under its own steam shall not harbour environmental sustainability. This also has crucial policy implications and manifestations of active policy responses for more inclusive 
and sustainable growth. In terms of financial development in ASEAN economies, the evidence on hand indicates that the increase in credit creation by the banking sector (bank credit over bank deposit) adversely affects the environment. This is intuitive as the banking credit system is mainly used to foster the lending channel for industries, which are not 'green' but are engaged in intensive 'energy consumption'. The financial development in terms of capital market development brought us interesting and contrasting results. We found contrasting results for the capital market expansion (the number of listed companies) on $\mathrm{CO}_{2}$ emission. Especially, the estimates by FMOLS indicates a positive impact, yet the estimates provided by the DOLS indicated a negative impact on environmental degradation. At this juncture, given the fact that the estimates by the DOLS are more robust against bias we conclude that this measure of financial development i.e. the number of listed companies will decrease the level of $\mathrm{CO}_{2}$ emissions. In a nutshell, we conclude that rapid economic growth and FDI can have unintended ecological consequences for the ASEAN economies. In the policy context, it is vital to focus on the more sustainable economic growth by allocating resources to environmental friendly sectors of the economy. The presence of a weak evidence on EKC reflects the importance of active policy responses. It is also advisable to direct the flows of FDI into more sustainable and greener sectors of the economy. In terms of financial development, it is also vital to allocate the financial resources to the environmental friendly sectors of the economy and hence, green finance is the way forward for the emerging ASEAN.

In this study we focused on the $\mathrm{CO}_{2}$ emissions due to their ecological and environmental significance, however, for further research we propose that the framework of the subject study can be extended by inclusion of the Ecological footprints in analysis. Further research may also include the regulatory aspect and role of innovations and R \& D in the renewable sectors of the ASEAN region to overcome the adverse and unintended consequences of the subject factors. 


\section{References}

Abbasi, F., Riaz, K. (2016). CO2 emissions and financial development in an emerging economy: an augmented VAR approach. Energy Policy 90, pp. 102-114.

Abdouli, M., Hammami, S. (2017), Investigating the causality links between environmental quality, foreign direct investment and economic growth in MENA countries. International Business Review, 26, pp. 264-278.

Ackerman, F. (2017), Worst-Case Economics: Extreme Events in Climate and Finance Anthem Press, New York, NY (2017)

Al-Mulali, U., Ozturk, I., (2016). The investigation of environmental Kuznets curve hypothesis in the advanced economies: the role of energy prices, Renewable \& Sustainable Energy Reviews. 54, pp. $1622-1631$.

Al-Mulali, U., Tang, C.F., 2013. Investigating the validity of pollution haven hypothesis in the gulf cooperation council (GCC) countries. Energy Policy, 60, pp. 813-819.

Apergis, N., 2016. Environmental Kuznets curves: new evidence on both panel and country-level CO2 emissions. Energy Economics, 54, pp. 263-271.

ASEAN Investment Report (2018), ASEAN Investment Report 2018, Forign Direct Investment and the Digital Economy in ASEAN, available at https://asean.org/asean-investment-report-2018published/ accessed on $15^{\text {th }}$ December 2018.

Atasoy, B.S., 2017. Testing the environmental Kuznets curve hypothesis across the U.S.: evidence from panel mean group estimators. Renewable \& Sustainable Energy Reviews, 77, pp. 731-747.

Bagehot, W. (1873). Lombard Street: A Description of the Money Market. London: John Murray, Reprinted with introduction by Hartley Withers. London: William Clowes and Sons, 1924.

Baek, J. (2015), Environmental Kuznets curve for CO2 emissions: The case of Arctic countries, Energy Economics, Volume 50, pp. 13-17.

Beck, T. (2012). Finance and Growth: Lessons from the literature and the recent crisis, July 2012. Prepared for the LSE Growth Commission.

Bekhet, H.A., Matar, A., Yasmin, T., 2017. CO2 emissions, energy consumption, economic growth, and financial development in GCC countries: dynamic simultaneous equation models. Renewable \& Sustainable Energy Reviews, 70, pp. 117-132

Borio, C. (2011), "Rediscovering the macroeconomic roots of financial stability policy: journey, challenges and a way forward", Working Paper No. 354, BIS.

Brajer, V. Mead, R. W. Xiao, F. (2009), Health benefits of tunneling through the Chinese environmental Kuznets curve (EKC), Ecological Economics, 66, (4) pp. 674-686. 
Campiglio, E. (2016), Beyond carbon pricing: The role of banking and monetary policy in financing the transition to a low-carbon economy, Ecological Economics, 121, pp. 220-230,

Caviglia-Harris, J. L. Chambers, D. Kahn, J. R. (2009), Taking the "U" out of Kuznets: A comprehensive analysis of the EKC and environmental degradation, Ecological Economics, 68 (4), pp 1149-1159.

Cetin, M. \& Ecevit, E. (2017), The Impact of Financial Development on Carbon Emissions under the Structural Breaks: Empirical Evidence from Turkish Economy, International Journal of Economic Perspectives, 2016, Volume 11, Issue 1, 64-78.

Chandran, V.G.R., Tang, C.F., 2013. The impacts of transport energy consumption, foreign direct investment and income on $\mathrm{CO} 2$ emissions in ASEAN-5 economies. Renewable \& Sustainable Energy Reviews, 24, pp 445-453.

Chang, S.C., 2015. Effects of financial developments and income on energy consumption. Int. Rev. Econ. Finance. 35, 28-44.

Charfeddine, L., Khediri, K.B., 2016. Financial development and environmental quality in UAE: cointegration with structural breaks, Renewable \& Sustainable Energy Reviews, 55, pp. 13221335 .

Čihák, M., \& Demirgüç-Kunt, A. 2012. feyen E., Levine R. Benchmarking Financial Development Around the World, Electronic resource, World Bank Policy Research Working Paper, 6175, 58.

Çoban, S., Topcu, M., 2013. The nexus between financial development and energy consumption in the EU: a dynamic panel data analysis. Energy Economics, 39, pp. 81-88.

Cole, M. A. Fredriksson, P. G (2009), Institutionalized pollution havens, Ecological Economics, 68, 4, pp.1239-1256.

Das, K. Lin, D. Y. (2018), Asean states have fared well. Now, to continue doing so, McKinsey \& Company Home, McKinsey Global Institute, available at https://www.mckinsey.com/mgi/overview/in-the-news/asean-states-have-fared-well-now-tocontinue accessed on 7th December 2018.

Dogan, E., Seker, F., 2016. The influence of real output, renewable and non-renewable energy, trade and financial development on carbon emissions in the top renewable energy countries. Renewable \& Sustainable Energy Reviews, 60, 1074-1085.

Esteve, V., Tamarit, C., 2012. Is there an environmental Kuznets curve for Spain? Fresh evidence from old data. Economic Modelling. 29, pp. 2696-2703

FocusEconomics(2018), Economic Forecasts from the World's Leading Economists, Economic Snapshot for ASEAN, available at https://www.focus-economics.com/regions/asean 
Fosten, J., Morley, B., Taylor, T., 2012. Dynamic misspecification in the environmental Kuznets curve: evidence from $\mathrm{CO} 2$ and SO2 emissions in the United Kingdom. Ecological Economics, 76, pp. 25-33.

Friedman, M. 1937. The use of ranks to avoid the assumption of normality implicit in the analysis of variance. Journal of the American Statistical Association 32: 675-701.

Frees, E. W. 1995. Assessing cross-sectional correlations in panel data. Journal of Econometrics 69: 393-414.

Frees, E. W. 2004. Longitudinal and Panel Data: Analysis and Applications in the Social Sciences. Cambridge: Cambridge University Press.

Goldsmith, R. W. (1969). Financial Structure and Development, New Haven, Yale University Press.

Grafton, R. Q. Jotzo, F. Wasson, M. (2004), Financing sustainable development: Country Undertakings and Rights for Environmental Sustainability CURES, Ecological Economics, Volume 51, (1-2). Pages 65-78,

Grossman, G. M.; Krueger, A. B. (1991). "Environmental impacts of a North American Free Trade Agreement". National Bureau of Economic Research Working Paper 3914, NBER. Cambridge MA. doi:10.3386/w3914.

Ghosh, S., 2010. Examining carbon emissions economic growth nexus for India: a multivariate cointegration approach. Energy Policy 38, 3008-3014.

Gurley, J. and Shaw, E. (1960). Money in a Theory of Finance, Washington: Brookings.

He, J. (2006) Pollution haven hypothesis and environmental impacts of foreign direct investment: The case of industrial emission of sulfur dioxide (SO2) in Chinese provinces, Ecological Economics, Volume 60 (1), pp. 228-245.

Hitam, M.B., Borhan, H.B., 2012. FDI, growth and the environment: impact on quality of life in Malaysia. Procedia Soc. Behav. Sci. 50, pp. 333-342.

Hossfeld, O. 2010. Equilibrium Real Effective Exchange Rates and Real Exchange Rate Misalignments: Time Series vs. Panel Estimates FIW Working Paper No. 65. Available online: https://www.econstor.eu/bitstream/10419/121070/1/N_065.pdf

Islam, F., Shahbaz, M., Ahmed, A.U., Alam, M.M., 2013. Financial development and energy consumption nexus in Malaysia: a multivariate time series analysis. Econ. Model. 30, 435-441.

Jalil, A., Feridun, M., 2011. The impact of growth, energy and financial development on the environment in China: a cointegration analysis. Energy Econ. 33, 284-291 
Javid, M., Sharif, F., 2016. Environmental Kuznets curve and financial development in Pakistan. Renewable \& Sustainable Energy Reviews. 54, pp. 406-414.

Jiang, L., Zhou, H.-F., Bai, L., Zhou, P., 2017. Does foreign direct investment drive environmental degradation in China? An empirical study based on air quality index from a spatial perspective. J. Clean. Production pp. 1-9.

Kao, C., \& Chiang, M. H. 2001. On the estimation and inference of a cointegrated regression in panel data. In Nonstationary panels, panel cointegration, and dynamic panels (pp. 179-222). Emerald Group Publishing Limited.

Kao, C. 1999. Spurious regression and residual-based tests for cointegration in panel data. Journal of Econometrics 90: 1-44.

Katircioglu, S. (2012), Financial Development, International Trade and Economic Growth: The Case of Sub-Saharan Africa, Ekonomista, 15 (1): 117-127.

Katircioglu, S. T. \& Taspinar, N. (2017), Testing the Moderating Role of Financial Development in an Environmental Kuznets Curve: Empirical Evidence from Turkey, Renewable \& Sustainable Energy Reviews, 68 (1): 572-586.

Kindleberger, C.P. (1978), Manias, Panics, and Crashes: A History of Financial Crises, Macmillan, London.

Kivyiro, P., Arminen, H., 2014. Carbon dioxide emissions, energy consumption, economic growth, and foreign direct investment: causality analysis for Sub-Saharan Africa. Energy 74, 595606.

Lantz, V. Feng, Q. (2006), Assessing income, population, and technology impacts on CO2 emissions in Canada: Where's the EKC? Ecological Economics, Volume 57 (2), Pages 229-238.

Lau, L.S., Choong, C.K., Eng, Y.K., 2014. Investigation of the environmental Kuznets curve for carbon emissions in Malaysia: do foreign direct investment and trade matter? Energy Policy 68, 490-497.

Lee, J.W., 2013. The contribution of foreign direct investment to clean energy use, carbon emissions and economic growth. Energy Policy 55, 483-489.

Leimbach, M. Roming, N. Schultes, A. Schwerhoff, G. (2018) Long-Term Development Perspectives of Sub-Saharan Africa under Climate Policies, Ecological Economics, 144, pp. 148159 ,

Lindmark, M. (2002), An EKC-pattern in historical perspective: carbon dioxide emissions, technology, fuel prices and growth in Sweden 1870-1997, Ecological Economics, 42, (1-2) pp. 333-347, 
McKinnon, R. I. (1973). Money and Capital in Economic Development, Washington D.C., Brooking Institution.

Minsky, H.P. (1974), “The modeling of financial instability: an introduction", Modeling and Simulation, Conference Proceedings of the Fifth Annual Pittsburgh Conference, Pittsburgh.

Minsky, H.P. (1982), “The federal reserve between a rock and a hard place”, in Can It Happen Again? Essay on Instability and Finance, M.E. Sharpe, Armonk, NY, pp. 192-202.

Nasir, M., Ahmed, F., Ahmed, M. and Wu, J. (2015). Financial and economic stability as 'two sides of a coin': Non-crisis regime evidence from the UK based on VECM. Journal of Financial Economic Policy, 7, pp. 327-353.

Narayan, P.K., Narayan, S., 2010. Carbon dioxide emissions and economic growth: panel data evidence from developing countries. Energy Policy 38, pp. 661-666.

Naughton, H. T. (2014), To shut down or to shift: Multinationals and environmental regulation, Ecological Economics, Volume 102, pp. 113-117,

Nguyena, Y. N. Brown, K. Skully, M. (2017), Economic Development Levels and the Finance and Growth Nexus, Annual Meeting American Economics Association, Chicago, IL (January 6-8, 2017). Available at https://www.aeaweb.org/conference/2017/preliminary.

Omri, A., Daly, S., Rault, C., Chaibi, A., 2015. Financial development, environmental quality, trade and economic growth: what causes what in MENA countries. Energy Economics, 48, pp. $242-252$.

Onafowora, O.A., Owoye, O., 2014. Bounds testing approach to analysis of the environment Kuznets curve hypothesis. Energy Economics. 44, pp. 47-62

Ozturk, I., Acaravci, A., 2013. The long-run and causal analysis of energy, growth, openness and financial development on carbon emissions in Turkey. Energy Economics, 36, pp. 262-267

Özokcu, S., Özdemir, Ö., 2017. Economic growth, energy, and environmental Kuznets curve. Renewable \& Sustainable Energy Reviews. 72, pp. 639-647

Pal, D., Mitra, S.K., 2017. The environmental Kuznets curve for carbon dioxide in India and China: growth and pollution at crossroad. J. Policy Model 39, 371-385.

Pao, H.-T., Tsai, C.-M., 2011. Multivariate Granger causality between CO2 emissions, energy consumption, FDI (foreign direct investment) and GDP (gross domestic product): evidence from a panel of BRIC (Brazil, Russian Federation, India, and China) countries. Energy 36, pp. 685-693.

Paramati, S.R., Ummalla, M., Apergis, N., 2016. The effect of foreign direct investment and stock market growth on clean energy use across a panel of emerging market economies. Energy Econ. $56,29-41$. 
Pazienza, P., 2015a. The relationship between CO2 and foreign direct investment in the agriculture and fishing sector of OECD countries: evidence and policy considerations. Intellect. Econ. 9, 5566.

Pazienza, P., 2015b. The environmental impact of the FDI inflow in the transport sector of OECD countries and policy implications. Int. Adv. Econ. Res. 21, 105-116.

Pedroni, P. 1996. Fully Modified OLS for Heterogeneous Cointegrated Panels and the Case of Purchasing Power Parity; Manuscript; Department of Economics, Indiana University, Available online: http://web.williams.edu/Economics/pedroni/WP-96-20.pdf.

Pedroni, P. 1999. Critical values for cointegration tests in heterogeneous panels with multiple regressors. Oxford Bulletin of Economics and Statistics 61: 653-670.

Pedroni, P. 2001. Fully modified OLS for heterogeneous cointegrated panels. In Nonstationary Panels, Panel Cointegration, and Dynamic Panels; Advances in Econometrics; Baltagi, B.H., Fomby, T.B., Hill, R.C., Eds.; Emerald Group Publishing Limited; Volume 15, pp. 93-130.

Pedroni, P. 2004. Panel cointegration: Asymptotic and finite sample properties of pooled time series tests with an application to the PPP hypothesis. Econometric Theory 20: 597-625.

Pesaran, M. H. 2004. General diagnostic tests for cross section dependence in panels. University of Cambridge, Faculty of Economics, Cambridge Working Papers in Economics No. 0435.

Raworth, K., 2017. Doughnut Economics: Seven Ways to Think Like a 21st-Century Economist. Random House Business (ISBN-13: 978-1847941374).

Rezza, A. A. (2013) FDI and pollution havens: Evidence from the Norwegian manufacturing sector, Ecological Economics, Volume 90, Pages 140-149.

Richardson, R. B. (2018), Book Review: Worst-Case Economics: Extreme Events in Climate and Finance, Frank Ackerman, Anthem Press, New York, NY (USA) (2017), 208 pp. ISBN: 9781783087075, Ecological Economics, 150, pp. 361-362,

Salahuddin, M., Alam, K., Ozturk, I., Sohag, K., 2018. The effects of electricity consumption, economic growth, financial development and foreign direct investment on $\mathrm{CO} 2$ emissions in Kuwait. Renewable \& Sustainable Energy Reviews. 81, 2002-2010.

Saqib, N. \& Waheed, A. (2011), Financial Sector Reforms and Macroeconomic Performance: Policy Simulations Based on Financial Macroeconomic Model for Pakistan, International Journal of Economic Perspectives, Volume 5, Issue 3, pp. 241-260.

Sadorsky, P., 2010. The impact of financial development on energy consumption in emerging economies. Energy Policy 38, 2528-2535. 
Sadorsky, P., 2011. Financial development and energy consumption in Central and Eastern European frontier economies. Energy Policy 39, 999-1006.

Sbia, R., Shahbaz, M., Hamdi, H., 2014. A contribution of foreign direct investment, clean energy, trade openness, carbon emissions and economic growth to energy demand in UAE. Econ. Model. 36, 191-197.

Sephton, P., Mann, J., 2013. Further evidence of an environmental Kuznets curve in Spain. Energy Econ. 36, 177-181

Shafik, N. (1994), "Economic Development and Environmental Quality: An Econometric Analysis." Oxford Economic Papers, Volume, 46, pp. 757-773.

Shaw, E. S. (1973). Financial Deepening in Economic Development, New York, Oxford University Press.

Shahbaz, M., Lean, H.H., Shabbir, M.S., 2012a. Environmental Kuznets curve hypothesis in Pakistan: cointegration and Granger causality. Renew. Sust. Energ. Rev. 16, 2947-2953.

Shahbaz, M., Zeshan, M., Afza, T., 2012b. Is energy consumption effective to spur economic growth in Pakistan? New evidence from bounds test to level relationships and Granger causality tests. Econ. Model. 29, 2310-2319.

Shahbaz, M., Mutascu, M., Azim, P., 2013a. Environmental Kuznets curve in Romania and the role of energy consumption. Renewable \& Sustainable Energy Reviews. 18, 165-173.

Shahbaz, M., Tiwari, A.K., Nasir, M., 2013c. The effects of financial development, economic growth, coal consumption and trade openness on $\mathrm{CO} 2$ emissions in South Africa. Energy Policy $61,1452-1459$

Shahbaz, M., Nasreen, S., Abbas, F., Anis, O., 2015. Does foreign direct investment impede environmental quality in high-, middle-, and low-income countries? Energy Econ. 51, 275-287.

Shahbaz, M., Shahzad, S.J.H., Ahmad, N., Alam, S., 2016a. Financial development and environmental quality: the way forward. Energy Policy 98, 353-364.

Shahbaz, M., Jam, F.A., Bibi, S., Loganathan, N., 2016b. Multivariate granger causality between $\mathrm{CO} 2$ emissions, energy intensity and economic growth in Portugal: evidence from cointegration and causality analysis. Technol. Econ. Dev. Econ. 22, 47-74.

Shahbaz, M., Omay, T., Roubaud, D., 2017c. The sharp and smooth breaks unit root testing of renewable energy consumption: the way forward. Paper Presented in 1st International Conference on Energy, Finance and the Macroeconomy, 22-24 November 2017. Montpellier Business School, Montpellier, France 
Shahbaz, M. Nasir, M. A. Roubaud, D. (2018), Environmental degradation in France: The effects of FDI, financial development, and energy innovations, Energy Economics, Volume 74, Pages 843-857.

Shahbaz, M., Sinha, A. (2019). Environmental Kuznets curve for CO2 emissions: a literature survey. Journal of Economic Studies, 46(1), pp. 106-168.

Shen, C.-H. and Lee, C. C. (2006). Same Financial Development yet Different Economic Growth: Why? Journal of Money, Credit and Banking, 38, 1907-1944.

Sinha, A., Shahbaz, M. (2018). Estimation of Environmental Kuznets Curve for CO2 emission: Role of renewable energy generation in India. Renewable Energy, 119, 703-711.

Sinha, A., Shahbaz, M., Balsalobre, D. (2017). Exploring the relationship between energy usage segregation and environmental degradation in N-11 countries. Journal of Cleaner Production, 168, 1217-1229.

Solarin, S.A., Al-Mulali, U., Musah, U., Ozturk, I., 2017. Investigating the pollution haven hypothesis in Ghana: an empirical investigation. Energy 124, 706-719.

Song, M.-L., Zhang, W., Wang, S.H., 2013. Inflection point of environmental Kuznets curve in Mainland China. Energy Policy 57, 14-20.

Soukhakian, B. (2007), Financial Development, Trade Openness and Economic Growth in Japan: Evidence from Granger Causality Tests, International Journal of Economic Perspectives, Volume 1, Issue 3, pp. 118-127.

Soukhakian, N. (2007), Financial Development and Economic Growth in Iran: Evidence From CoIntegration and Causality Tests, International Journal of Economic Perspectives, Volume 1, Issue 2, pp. 56-63.

Tamazian, A., Chousa, J.P., Vadlamannati, K.C., 2009. Does higher economic and financial development lead to environmental degradation: evidence from BRIC countries. Energy Policy 37, 246-253.

Tamazian, A., Rao, B.B., 2010. Do economic, financial and institutional developments matter for environmental degradation? Evidence from transitional economies. Energy Econ. 32, 137-145

Tang, C.F., Tan, B.W., 2015. The impact of energy consumption, income and foreign direct investment on carbon dioxide emissions in Vietnam. Energy 79, 447-454

Tiwari, A.K., Shahbaz, M., Hye, Q.M.A., 2013. The environmental Kuznets curve and the role of coal consumption in India: cointegration and causality analysis in an open economy. Renew. Sust. Energ. Rev. 18, 519-527 
Liu, Y., Hao, Y., Gao, Y., 2017. The environmental consequences of domestic and foreign investment: evidence from China. Energy Policy 108, 271-280.

Westerlund, J. 2005. New simple tests for panel cointegration. Econometric Reviews 24: 297-316.

Yuan, F. Gallagher, K. P. (2018), Greening Development Lending in the Americas: Trends and Determinants, Ecological Economics, Volume 154, Pages 189-200,

Zhang, Y.J., 2011. The impact of financial development on carbon emissions: an empirical analysis in China. Energy Policy 39, 2197-2203.

Zhang, C., Zhou, X., 2016. Does foreign direct investment lead to lower CO2 emissions? Evidence from a regional analysis in China. Renewable \& Sustainable Energy Reviews. 58, 943-951.

Zhu, H., Duan, L., Guo, Y., Yub, K., 2016. The effects of FDI, economic growth and energy consumption on carbon emissions in ASEAN-5: evidence from panel quantile regression. Economic Modelling. 58, pp. 237-248. 